\title{
Chris Berry, Lu Xinyu, Lisa Rofel (eds.), The New Chinese Documentary Film Movement: For the Public Record
}

Hong Kong, Hong Kong University Press, 2010, 320 pp.

Judith Pernin

Translator. N. Jayaram

\section{CpenEdition}

Journals

Electronic version

URL: http://journals.openedition.org/chinaperspectives/5591

DOI: 10.4000/chinaperspectives.5591

ISSN: 1996-4617

\section{Publisher}

Centre d'étude français sur la Chine contemporaine

\section{Printed version}

Date of publication: 30 July 2011

Number of pages: 80-81

ISSN: 2070-3449

\section{Electronic reference}

Judith Pernin, «Chris Berry, Lu Xinyu, Lisa Rofel (eds.), The New Chinese Documentary Film Movement: For the Public Record », China Perspectives [Online], 2011/2 | 2011, Online since 30 June 2011, connection on 21 September 2020. URL : http://journals.openedition.org/chinaperspectives/5591 ; DOI : https://doi.org/10.4000/chinaperspectives.5591

This text was automatically generated on 21 September 2020 .

(c) All rights reserved 


\section{Chris Berry, $\mathrm{Lu}^{1}$ Xinyu, Lisa Rofel (eds.), The New Chinese Documentary Film Movement: For the Public Record}

Hong Kong, Hong Kong University Press, 2010, 320 pp.

\section{Judith Pernin}

Translation : N. Jayaram

“Any attempt to understand China's visual culture today must start from an understanding of the New Documentary Movement."2 Such is the importance this book's editors attach to the crop of independent films emerging from China since the early 1990s. Born of the efforts of a few individuals who decided to make more personal documentaries while working for Chinese television stations, the movement grew considerably with the appearance of DV cameras. Digital cinematography's immediacy and its facility of distribution nurtured a flowering of new visual practices that in turn fuelled discussions on cinema and society. The aim of The New Chinese Documentary Movement: For the Public Record is to give voice to scholars dealing with this cinematographic current in its
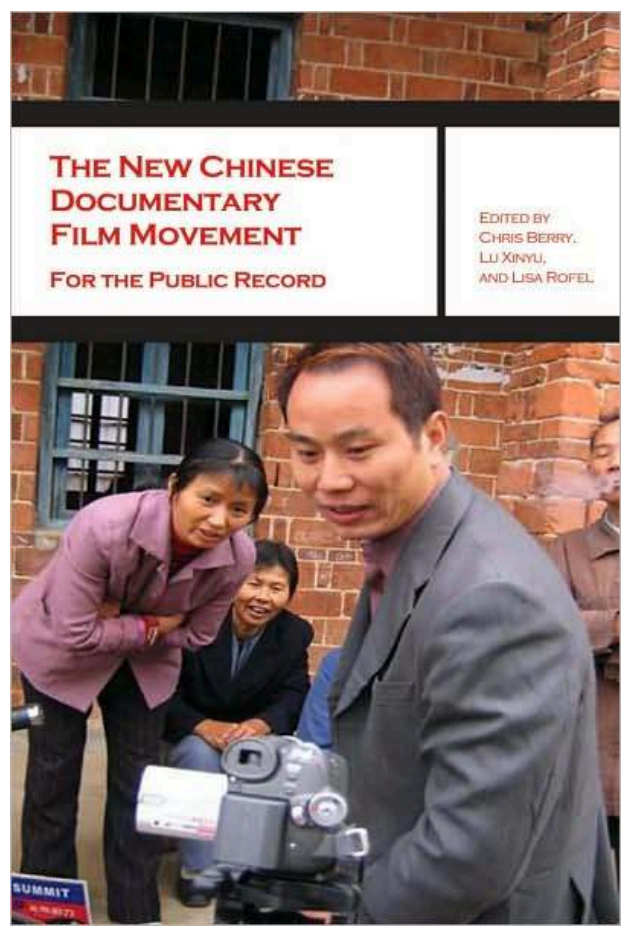
social dimension in particular.

The book's editors are major figures in Chinese visual studies: Chris Berry, professor in the Department of Media and Communication at Goldsmiths, University of London, 
author and editor of several books on Chinese Cinema; ${ }^{3} \mathrm{Lu}$ Xinyu, professor and director of the Broadcasting and Television Department of the Journalism School at Fudan University in Shanghai, credited with the very first studies on independent Chinese documentaries; ${ }^{4}$ and Lisa Rofel, professor of anthropology at the University of California, Santa Cruz, an expert on issues of gender and sexuality in contemporary Chinese culture. ${ }^{5}$ The book has contributions by scholars in Asian studies, comparative literature, film studies, and sociology as well as an article by one of the first directors in the documentary movement, Wu Wenguang. The New Chinese Documentary Movement has four parts: a historical introduction is followed by a section devoted to identity, a third dealing with the question of the public, and the last focusing on the relationship between director and filmed subject.

3 Lu Xinyu's chapter, which begins the book's historical section, revisits the polemics generated by her 2003 book Documenting China, a compilation of historical and theoretical articles and interviews with directors. The book was one of the first academic publications on the subject. Lu recounts the movement's birth from what she calls the "ruins of Utopia," and describes also the paradoxical relationship between indie filmmakers and the Chinese televisual system. Lu returns to those themes in this chapter, attempting a rereading of the movement's history, notably through its link to film theory. While the directors' first impulse stemmed from the need for "rethinking television documentary practices," the gradual adoption of indie methods by Chinese television chains compelled them to question their work in a theoretical light. In Lu's view, a more aesthetic and individual approach that predominates in today's documentaries corresponds to this theoretical reconfiguration and emergence of a new generation of directors who took no part in the 1989 movement.

Closing the book's historical section, Wu Wenguang's "DV: Individual Filmmaking"7 is a first-person account of his conversion to the DV camera while filming Jianghu (1999). This tiny camera transformed his work and his conception of the documentary by revealing the true nature of this filmic form, which in his view is made to be "individual," detached from script constraints, and open and unpredictable. This text, earlier published in Chinese and celebrating the freedom afforded by DV, greatly influenced young filmmakers as well as scholars who developed - as Luke Robinson does elsewhere in the book - contingence theories of Chinese documentaries.

The book's second part, "Documenting Marginalization, or Identities New and Old," consists of two chapters that, while not without linkages, differ greatly from a theoretical viewpoint. It focuses on two categories of people who may be deemed to have a marginal identity (jobless workers and homosexuals). The first chapter is an expanded version of the Lu Xinyu article ${ }^{8}$ describing Wang Bing's famous film, West of the Tracks (2003), and attempts to extract a general redefinition of the relationship between the working class and history, but one that is nevertheless rather schematic, given the film's complexity.

6 In the next chapter, Chao Shi Yan, a doctoral candidate at New York University and expert on Chinese queer media representation, compares films dealing with female homosexuality. The Box, by Ying Weiwei (2001), is an elegant black-and-white film describing daily life, in particular the private life of two female partners. Unlike Dyke March (2004) by Shi Tou and Ming Ming, it is not an "engaged" film, but a very personal view of the protagonists' private lives. Shi Tou and Ming Ming, on the contrary, go beyond Ying's simple defence of individuality by appealing to "lesbianism 
as political identification and collective belonging through both their content and their production approaches" (p. 95).

7 The book's third section, "Publics, Counter-Publics, and Alternative Publics," looks at the films' "public" dimension from the point of view of their reception and distribution as well as their cinematographic value: their way of rendering a theme to the film's audience. Paola Voci, who teaches visual culture at the University of Otago, New Zealand, and has published China on Video: Smaller-Screen Realities (2010), deals in her contribution, "Blowup Beijing, The City as a Twilight Zone," with the city's representation in indie documentaries. Focusing on the marginalised in the "dark zones" of Beijing, "these documentaries also function as a critique of realism and suggest that what is real does not shine in the bright sun, but rather barely flickers in the dark." (p. 101). Voci seeks to show that through "performance" (in the sense of acting, of "performance art" as well as of the director's performance), these marginal communities acquire a visibility that, although "unavoidably limited, both temporally and spatially" (p. 100) facilitates "mutual legitimization" and lets them "participate in the making of an alternative cultural sphere" (p. 112).

This "alternative" space Voci speaks of is analysed in a different way in the next two chapters. The first, "Watching Documentary, Critical Public Discourses and Contemporary Urban Chinese Films Clubs," views the issue of the public from the angle of the films' reception. In this, Seio Nakajima applies his ethnographic studies to Beijing film clubs. ${ }^{9}$ He distinguishes among four categories of clubs and seeks to evaluate the extent to which they approximate the Habermassian notion of "public sphere" by analysing discussions there. The existence of these spaces facilitates the production of counter-discourses ("documentary films, as discourse, shown and viewed, and [...] discourses on documentary films," p.132). While not fitting into the concept of public sphere in the strictest sense, these film clubs nevertheless contribute towards critical discussions, Nakajima says.

In "Alternative Archive: China's Independent Documentary Culture," Chris Berry and Lisa Rofel attempt to define the cultural specificity of the public viewing these new documentaries. For Berry and Rofel, the 1989 Tiananmen movement and Deng Xiaoping's southern tour in 1992 were two historic events that shaped the development of an alternative Chinese culture. This relied on rejection of political violence as well as on a rejection of mainstream and commercial culture that emerged with the rise of market economy since 1992. Neither the term civil society nor "independence" quite manages to define this culture, which developed in the 1990s, in their view. They "suggest that the term 'alternative' best captures the way in which the 1989/1992 conjuncture shapes the cultural and artistic practices that have developed outside the new state-corporate hegemonic culture of China today" (p. 136). The authors proceed to establish the "alternative" nature of these documentaries, showing how they mount a criticism of "both commercial and governmental pressures and constraints" (p. 148) in the way they treat the films' subjects, as well as in their organisation of events in specific places and their function as archives of popular memory.

The book's last section, "Between filmmaker and subject: Recreating realism," focuses on the interactions between the filmmakers and their work, exploring the different modes of their intervention. Bérénice Reynaud, who teaches at California Institute of the Arts and has written numerous articles and books on Chinese cinema, offers in her chapter "Translating the Unspeakable" a sound analysis of Wu Wenguang's 
documentaries. She picks out in his films the Three Listening Modes as per Michel Chion's theory (semantic, causal, reduced) ${ }^{10}$ which are activated by, among others, Wu's own voice. The problem of the director's voice presence - redoubling that of his position vis-à-vis his work - seems to haunt $\mathrm{Wu}$ as he sometimes decides to cut out his voice or to let it hover on the film's soundtrack, making of his presence "an imperfect acousmêtre" 11 and creating "uncertainty concerning the subject of enunciation" (p. 167). The next, "From 'Public' to 'Private': Chinese Documentary and the Logic of Xianchang," is one of the book's most stimulating chapters. Luke Robinson, who teaches at the Institute of Film and TV Studies, University of Nottingham, examines the auteur's position in terms of his degree of control over filming. He shows that the passage from "public documentaries" (which seek to consider general issues through specific instances) to "private documentaries" (focused more on individual issues) in the 1990s "stems less from differences in content than from the forms used to frame this material" (p. 180). The former's "metonymical or metaphorical" character that facilitates generalisations on public issues through specific cases, fades out during the movement's second half, ceding place to a celebration of particularities, corresponding also to directors' increasing inclination to accept "unforeseen and contingent events," instead of seeking to control the profilmic, i.e., all that the camera is recording.

In "Excuse Me Your Camera Is in My Face: Auteurial Intervention in PRC New Documentary," the distinction between direct cinema and cinéma vérité ${ }^{12}$ serves Yomi Braester (professor of comparative literature at the University of Washington, Seattle) in analysing the director's presence in the film. In Braester's view, the former, purely observational style readily corresponds to the imperatives of xianchang ${ }^{13}$ thatWu Wenguang has promoted; the latter, intrusive and "manipulative," are analysed through the examples of three films - There is a Strong Wind in Beijing (1999), Home Video (2001), and The Railroad of Hope (2002).

In the book's last chapter (“'I am One of Them' and 'They Are My Actors": Performing, Witnessing and DV Image-Making in Plebian China"), Yiman Wang, who teaches film and digital media at the University of California, Santa Cruz, seeks to "analyse how [the films] redefine documentary ethics by configuring new relationships between the documentary maker and his or her subjects" (p. 217). The new documentary makers question the author's role as producer vis-à-vis the subject filmed as they use devices that blur the limits between enunciator (director) and enounced (protagonists), creating a form of "co-authorship."

14 The New Chinese Documentary Movement: For the Public Record sets in stone the expression "New Documentary Movement," which was coined in part by Lu Xinyu and has been criticised by some scholars or directors. The book likewise does not neglect the main themes central to these films (history, identity, power relationships, and realism). The annexes are very well conceived and contain references indispensable to anyone interested in the subject.

The book is neither a compilation of basic texts nor a representative summation of previous work in the domain, but sits at a maladroit midway point. Seio Nakajima's chapter rightly tries to make up for the paucity of studies on the reception of Chinese documentaries, based on fieldwork from the years 2003-2004 and published in 2005. The reality he depicts is much different from what it is now, the Beijing film clubs having changed greatly or disappeared, and replaced by other modes of viewing. Some chapters, such as those of Bérénice Reynaud or Luke Robinson, shed new light on indie 
documentarists, but others stick to well-worn problematics such as the insufficiently conceptualised but endlessly discussed one of the right terms to describe these films ("independents," "underground," or "alternative"?).

Finally, this book reveals the extent to which the film studies field is saturated with often similar analyses, and we might concur with Luke Robinson's conclusion: “Almost two decades after Bumming in Beijing [...], perhaps it is time for a considered reassessment both of how we approach the analysis of Chinese documentary film, and of what we understand its significance to be" (p. 194).

\section{NOTES}

1. The authors of this book have opted to write Lu Xinyu'name 吕新雨 as “Lu" instead of the more conventional pinyin transcription "Lü." To avoid any confusion, we retain "Lu" in our text as well, except in the footnotes, where the references will be written as "Lü."

2. Chris Berry, Lu Xinyu, Lisa Rofel (eds.), The New Chinese Documentary Film Movement: For the Public Record, Hong Kong, Hong Kong University Press, 2010, p. 4.

3. See Postsocialist Cinema in Post-Mao China: The Cultural Revolution After the Cultural Revolution, New York, London, Routledge, 2004; also (with Mary Farquhar), Cinema and the National: China on Screen, Hong Kong, Hong Kong University Press, 2006; he also edited (with Ying Zhu) TV China, Bloomington, Indiana University Press, 2009.

4. Lü Xinyu, Jilu Zhongguo: Dangdai Zhongguo jilupian yundong (Documenting China: the documentary movement in contemporary China), Beijing, Sanlian shudian, 2003.

5. She is the author of Desiring China: Experiments in Neoliberalism, Sexuality and Public Culture, Duke University Press, 2007, and Other Modernities: Gendered Yearnings in China after Socialism, University of California Press, 1999.

6. The New Chinese Documentary Film Movement: For the Public Record, Hong Kong, Hong Kong University Press, 2010, p. 23.

7. Earlier published in his Jingtou xiang ziji de yanjing yiyang, Shanghai, Wenyi chubanshe, 2001.

8. Published in Chinese in Lü Xinyu, "Tiexiqu': Lishi yu jieji yishi," Shuxie yu zhebi, Guilin, Guangxi Normal University Press, 2008, pp. 3-21; and an abridged version in English: "Ruins of the Future: Class and History in Wang Bing's Tiexi District," New Left Review, no. 31, 2005, pp. 125-36.

9. See "Films Clubs in Beijing: The Cultural Consumption of Chinese Independent Films," in Paul G. Pickowicz and Zhang Yingjin (eds.), From Underground to Independent: Alternative Film Culture in Contemporary China, Lanham, Rowman and Littlefield, 2006, pp. 161-208.

10. The three terms are the fruits of Pierre Schaeffer's research, reproduced by Michel Chion. Causal listening "pays attention to sound to discern all the indications that can inform the listener of its cause or source." "Reduced listening [...] is that which willingly and artificially abstracts cause and meaning (and, it may be added, effect), to focus on the sound itself, in its sensitive aspects of not only pitch and rhythm, but also grain, materiality, form, mass and volume." Finally, "semantic listening is one which in certain contexts concentrates on the coded sound signal (the best example of which is spoken language, but may also include morse or a code among prisoners), in order to decode this signal and get the message." These definitions by 
Michel Chion can be seen in the glossary on this page: http://www.michelchion.com/v1/ index.php?option=com_content\&task=view\&id=45\&Itemid $=60$.

11. Michel Chion defines acousmêtre thus: "In cinematic context, acousmêtre - as distinct from voice over clearly exterior to the image - is a person [whose voice only is heard but his image is not visible] defined in relation to the limits of the frame, where he is ceaselessly about to appear and holding on to this non-appearance as one the powers he wields over the content." The definition in French is available here: http://www.michelchion.com/v1/index.php? option=com_content\&task=view\&id=45\&Itemid=60

12. Direct Cinema is a documentary style that originated in the early 1960 s quasi-simultaneously in Canada, the United States, and France, in particular since the emergence of techniques to record synchronous sound, which allowed filmmakers to simultaneously gather sound and image directly on the spot. These new filming techniques helped eliminate mediation between the filmmaker and subject and to impart greater value to the latter's speech. Theoretical and practical work by filmmakers, critics, and ethnologists subsequently led to different currents and ways of looking at the documentary, from "pure" observation to participation, even staging. The expression "cinéma-vérité" is attributed to Edgar Morin, who worked with Jean Rouch in Chronique d'un été (A summer chronicle, 1961). He used the term in homage to Soviet filmmaker Dziga Vertov, who made news films named Kino-Pravda and had experimented with sound recording systems as far back as in the 1920s. The term "cinéma-vérité" came to mean a documentary style in which the camera is not hidden from the protagonist, leading to the emergence of "vérité" (truth or reality) with the help of directorial interventions (instructions, verbal exchanges, provocation of protagonists...).

13. Xianchang is a term meaning "scene," "place," and by extension "on place," "on scene." Many filmmakers have used it since the 1990s (Wu Wenguang, as well as Jia Zhangke) to refer to a mode of filming on the spot and at the very time of the events (rather than reconstitution in studio). Incorporating the characteristics of the place, this mode of filming also encourages inclusion of unforeseen events that might occur.

\section{AUTHORS}

\section{JUDITH PERNIN}

PhD candidate at the EHESS, Paris, and Research Fellow at the CEFC, Hong Kong. 